\title{
SPONTANEOUS OCCURRENCE AND DISPERSION \\ OF ARONIA $\times$ PRUNIFOLIA (MARSHALL) REHDER (ROSACEAE) IN POLAND ON THE EXAMPLE OF THE "BAGNA" BOG COMPLEX NEAR CHLEBOWO (WESTERN POLAND)
}

\author{
ZBiGNIEW CELKA, PIOTR SZKUDLARZ \\ Department of Plant Taxonomy, Faculty of Biology, \\ Adam Mickiewicz University \\ Umultowska 89, 61-614 Poznań, Poland \\ e-mail: zcelka@amu.edu.pl
}

(Received: March 2, 2009. Accepted: February 2, 2010)

\begin{abstract}
This study presents information on a new to Poland synanthropic species - Aronia xprunifolia (purple chokeberry). Purple chokeberry is cultivated worldwide as a fruit and decorative plant. In various regions of the world the process of its naturalisation outside the places of cultivation has been observed. In Europe, it is visible, among others, in Holland and Germany. In Poland, the first case was recorded in the "Bagna" bog complex near Chlebowo (Wielkopolska region). In this study, the distribution of Aronia $\times$ prunifolia in Poland has been presented (square ATPOL BC67, BC68) as well as its spread and conditions of occurrence.
\end{abstract}

KEY WORDS: Aronia xprunifolia, Rosaceae, peat bog, Chlebowo, Wielkopolska region, Poland, antropophyte, distribution.

\section{INTRODUCTION}

There are 65 species in the world that belong to the genus chockberry (Aronia, syn. Photinia) (Mabberley 1997). Chokeberry (German: Apfelbeere, Russian: арония) is a part of the family Rosaceae, the subfamiliy Maloideae. The name chokeberry derives from the Greek name of the medlar tree (Mespilus) (Seneta and Dolatowski 2008). There are three chokeberry species cultivated in Poland, namely Aronia arbutifolia (L.) Pers. (red chokeberry), Aronia melanocarpa (Michx.) Elliott (black chokeberry) and Aronia $\times$ prunifolia (Marshall) Rehder (purple chokeberry) - a hybrid between the two former species (Mirek et al. 2002; Seneta and Dolatowski 2008), though, all of them may also be known under other common names (compare: Kress 2001).

Species of the genus Aronia, occur spontaneously in Asia - from the Himalayas to Japan - and on Sumatra, as well as in the eastern, northern and central North America (Mabberley 1997; Kalkman 2004). Aronia xprunifolia occurs naturally in North America, from Newfoundland to Ontario, and in the south-from Indiana to Virginia (Gill and Pogge 1974). Chokeberries are shrubs with pointed, dark-purple buds adjacent to the shoots. The leaves are simple, elliptic or reversely oval, usually slightly acuminate at the apex, serrate or double-serrate at margin and the teeth ended with purple red glandules (similar glandules occur in the central nerve). Flowers diameter is up to $1 \mathrm{~cm}$ and they have five pistils arranged in an umbellate manner; petals are white or pink (Fig. 1). Chokeberries bloom in May and June. Their fruit are fleshy, pomes, red or black, small, $1.0-1.2 \mathrm{~cm}$ in diameter. They are formed from the low pistils with the participation of the flower's receptacle and have lasting calyx sepals. Shrubs reach 1.5-2(3) metres in height (Seneta and Dolatowski 2008). Aronias are tolerant of shading and grow in moist, acidic soils. They prefer swampy habitats and damp pine barrens (Fernald 1950; Gleason 1963).

The species occurring in Poland can be distinguished by the following features: Aronia arbutifolia has rhizomes; its roots and shoots are poorly branched and different parts of shrubs are strongly and permanently hairy; leaf venation is vague; leaves turn scarlet in the autumn, and fruit, also red, hang down from branches for a long time. Aronia melanocarpa does not produce rhizomes, shrubs are densely branched, various parts of the plant are glabrous and leaf venation is distinctive; leaves drop when green, and black fruit fall from branches early in the season. Aronia xprunifolia is a hybrid, of introgressive origin, between the two abovementioned species, partly polyploid. It has intermediate features: produces rhizomes, has scarlet leaves but less intensive in colour than those of A. arbutifolia and its dark purple fruits usually fall early in the season (Dolatowski 1996; Seneta and Dolatowski 2008). 

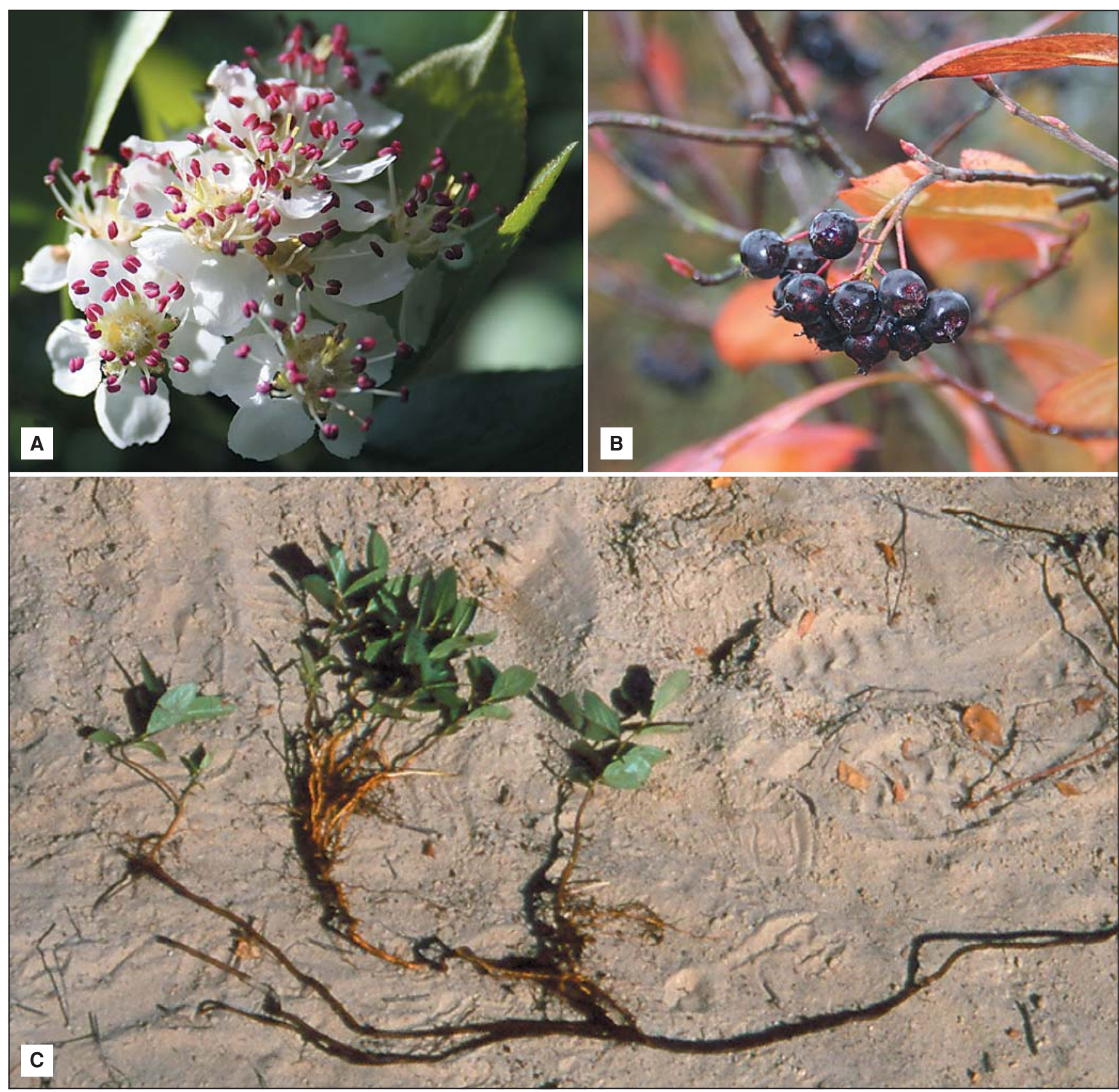

Fig. 1. Aronia $\times$ prunifolia.

Abbreviations: A - flowers; B - fruit bearing specimens; C - rhizomes.

Because of their decorative dark green leaves (light red in the autumn) and pretty flowers and fruits, chokeberries are valued and cultivated as ornamental plants, e.g. they work perfectly well in medium-tall hedgerows. Additionally, their fruits are valued for their high content of vitamin $\mathrm{P}$ (chokeberries are richest natural source of this vitamin). They also contain vitamins B2, B6, B9, C, E, and PP as well as microelements (molybdenum, manganese, copper, boron, iodine, and cobalt) and lots of anthocyanin pigments (Grochowski 1988).

Aronia $\times$ prunifolia was brought to England in 1800, and to Poland in 1833 - to the garden in Niedźwiedź near Kraków (Hereźniak 1992). In Poland, the most common of the cultivated chokeberries is purple chokeberry. According to Seneta and Dolatowski (2008), this species makes up all chokeberry plantations grown in Europe and Poland for centuries. The aim of this study is to present a new to Po- land synanthropic species - purple chokeberry - and the conditions of its occurrence and spread in the "Bagna" bog complex, near Chlebowo in northern Wielkopolska.

\section{MATERIAL AND METHODS}

The "Bagna" bog complex near Chlebowo, in northern Wielkopolska, covers about 500 ha and is located in the eastern part of the Notecka Forest (Puszcza Notecka). It takes up a basin-shaped depression slightly leaning towards the west and surrounded from the north, west and south by longitudinal dunes. The centre of the basin is situated at $52^{\circ} 44^{\prime} 11.6^{\prime \prime} \mathrm{N}, 16^{\circ} 45^{\prime} 24.5^{\prime \prime} \mathrm{E}$; the whole complex lies at 65-67 metres a.s.1. and has a flat bottom. Currently, the central part of the complex is a dead bog with numerous drainless peat pits. Their areas may cover even up to seve- 
ral hectares and depth up to 2.5 metres. In many peat pits, spontaneous processes of regeneration of a quaking bog take place (Ilnicki 1996). From the East and partially from the South, the complex is surrounded with transitional bogs and meadows, patches of a few arable lands and pine forest with a small participation of heathlands and sand grasslands.

Since the 19th century, the area of "Bagna" has been drained by a network of ditches which caused lowering of water level. This facilitated the exploitation of peat resources and finally resulted in the death of the bog (Schulz 1916). Extraction of peat was carried out gradually; in the past dozen years or so, the use of mechanical equipment resulted in the building of several hard surface roads across the bog. Such way of exploration also brought about formation of several dozen of large post-peat excavation ponds with open water surface, situated in the central part of the bog. Peat exploitation has been performed with various degrees of intensity until today.

The field studies, which started in 1990, involved mapping the distribution of purple chokeberry (on the basis of the 1:10 000 map), floristic inventories, phytosociological relevés made according to the Braun-Blanquet method and the analysis of the species occurrence conditions and spread in the whole bog complex. The collected herbarium specimens were deposited in the Herbarium of the Department of Plant Taxonomy of Adam Mickiewicz University in Poznań (POZ). The species names follow the work of Mirek et al. (2002). On the basis of the collected data, the distribution maps of chokeberry were prepared with the use of Corel Draw X3.

\section{RESULTS}

Alien species in the "Bagna" complex amount to about $15 \%$ of its flora. The dominant majority of anthropophytes

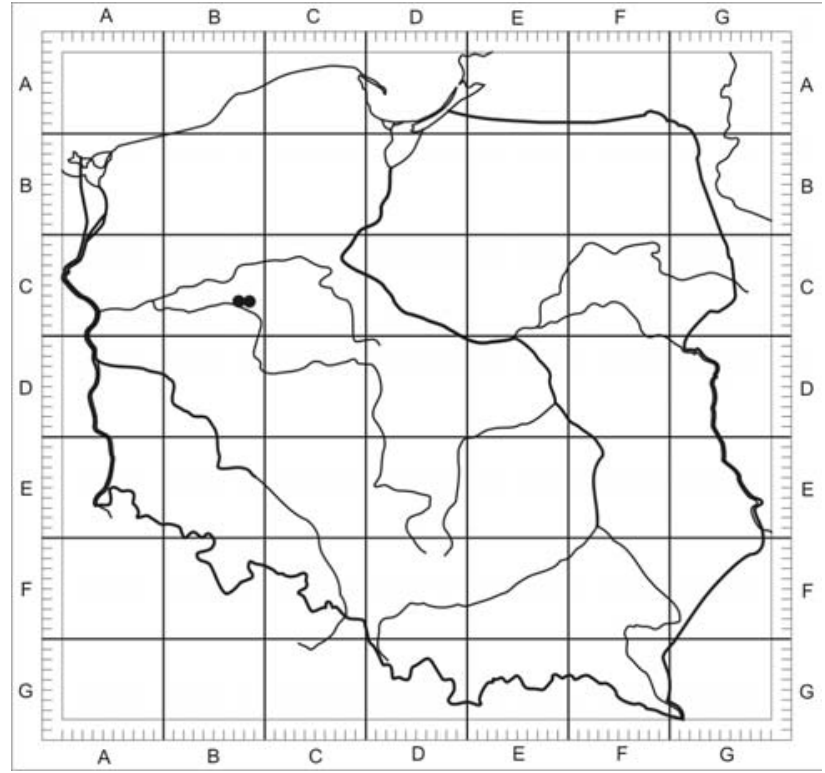

Fig. 2. Distribution of Aronia $\times$ prunifolia in Poland.

constitute taxa which occur sporadically and in small numbers, connected with ruderal habitats and dragged accidentally, especially on roads and their edges, e.g. Galinsoga parviflora, Cucurbita pepo or Oxalis stricta. Only one species among anthropophytes occurring within the complex is known for its large expansiveness. It is Aronia xprunifolia, which is a very common plant in the complex today. Spontaneous spread of Aronia $\times$ prunifolia in Poland has been observed so far only in the "Bagno" bog complex near Chlebowo (square ATPOL BC67) and in the forest neighbouring the complex (square ATPOL BC68) (Figs 2 and 3 ).

So far, in the area under study, several dozen of purple chokeberry concentrations have been observed, mainly in

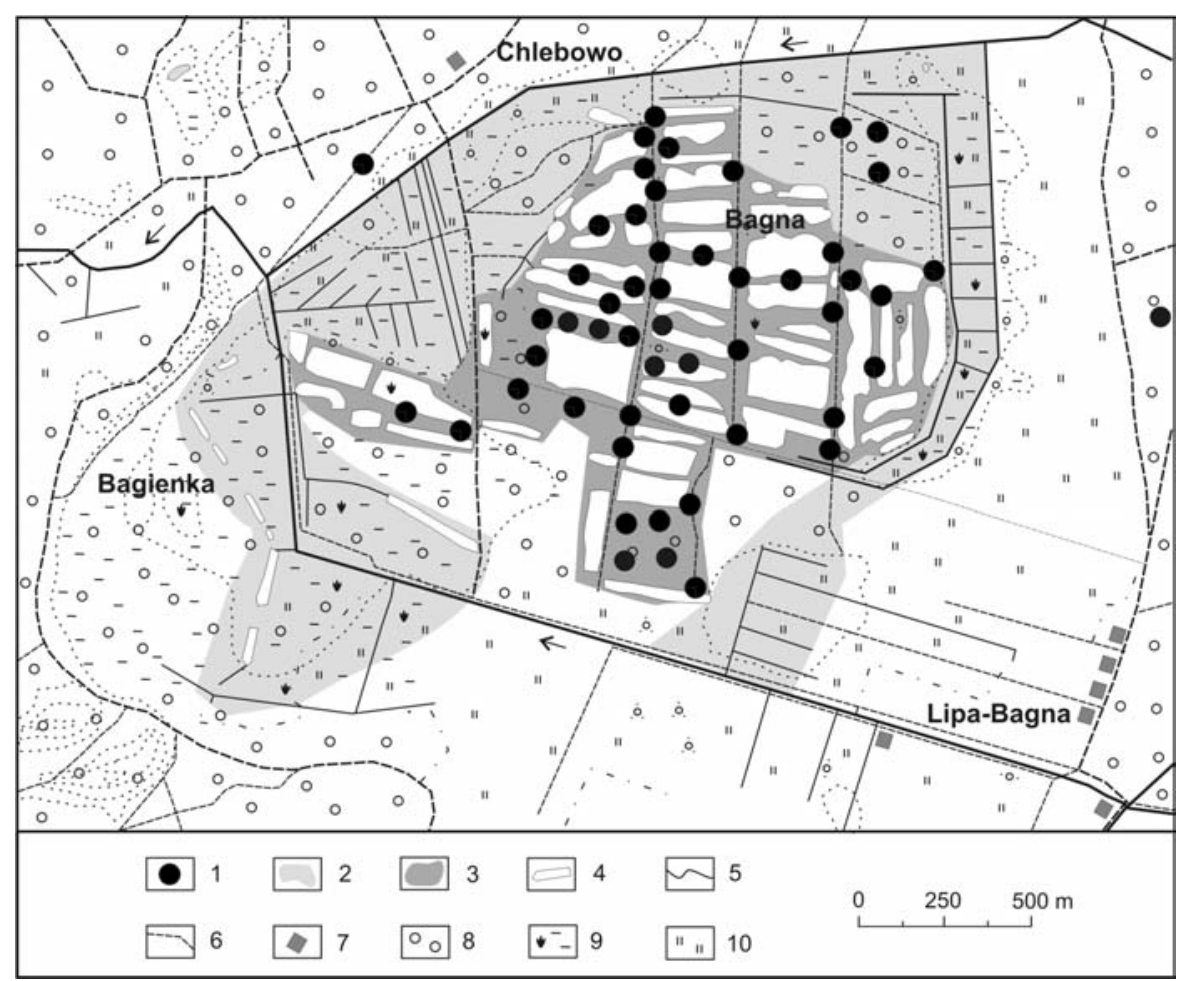

Fig. 3. Distribution of Aronia xprunifolia in the "Bagna" bog complex near Chlebowo. Abbreviations: 1 - species localities; 2 extent of the peat excavation area in the 19th century; 3 - extent of the peat excavation area in the 20th century; 4 - post-peat excavation ponds; 5 - watercourses; 6 - roads; 7 - built-up areas; 8 - forests; 9 - marshy areas; 10 - meadows. 


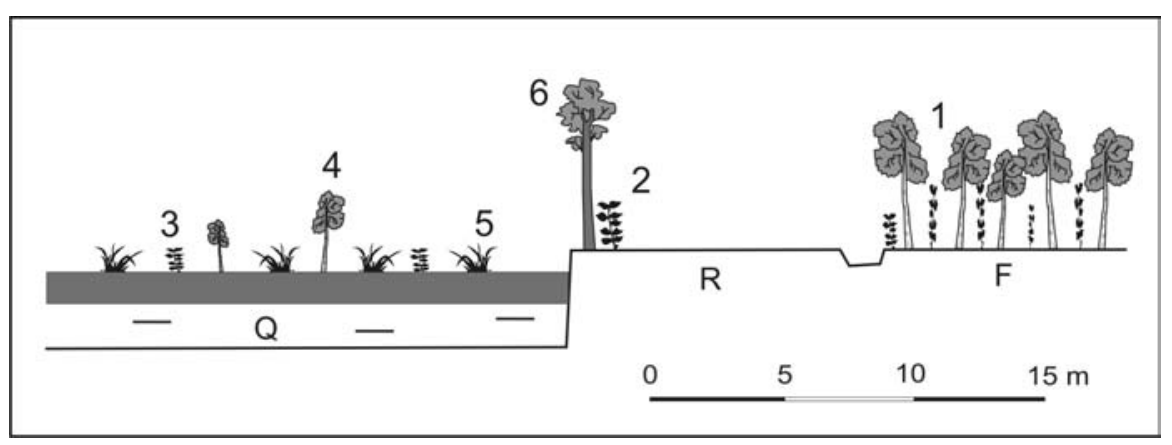

Fig. 4. Scheme of the central part of the "Bagna" bog complex near Chlebowo showing the sites of occurrence of Aronia $\times$ prunifolia. Abbreviations: 1 - Aronia $\times$ prunifolia in a birch forest $(\mathrm{F}) ; 2$ - by a roadside (R); 3 on a quaking bog (Q); 4 -Betula pubescens; 5 - Eriophorum sp.; 6 - Pinus sylvestris. the central part of the bog which is currently under the biggest human pressure (Figs 3 and 4). The participation of this species in the floristic recordings, carried out in the area where peat was excavated in the 20th century, reaches $60 \%$ (Fig. 5). Mass occurrence of Aronia xprunifolia is connected with roadsides as well as with birch forests and their fringes (see relevés 1-2). The species' participation in the floristic recordings conducted in these habitats reaches $40 \%$ and 60\%, respectively (Fig. 6). The first localities were observed in the beginning of the 21th century. They were situated on regenerating quaking bogs, in the area where peat was excavated in the 20th century, and in a fresh pine forest in which peat has not been excavated (see relevés 3-4). On quaking bogs, purple chokeberry grows accompanied by, among others, the species of the class Oxycocco-Sphagnetea - Oxycoccus palustris, Drosera rotundifolia, Eriophorum vaginatum and peatmosses (Fig. 4). The observed specimens reach a maximum height of $50-60 \mathrm{~cm}$, but they are already bearing fruits. In a fresh pine forest, purple chokeberry can be found at road edges several shoots distributed in a line in four concentrations, about $0.5 \mathrm{~m}$ from one another. The highest ones reach 70 $\mathrm{cm}$. In the purple chokeberry closest vicinity grow Vaccinium myrtillus, $V$. vitis-idaea, Deschampsia flexuosa, Juniperus communis, Padus serotina and Pinus sylvestris.

In open, sun-exposed areas, such as fringes of post-peat excavation ponds, purple chokeberry reaches 1.0-1.2 metres in height, is strongly branched and bears a large number of fruits. In proper conditions, even $20 \mathrm{~cm}$ long shoots produce fruits. In shadowed areas, in swampy birch forests,

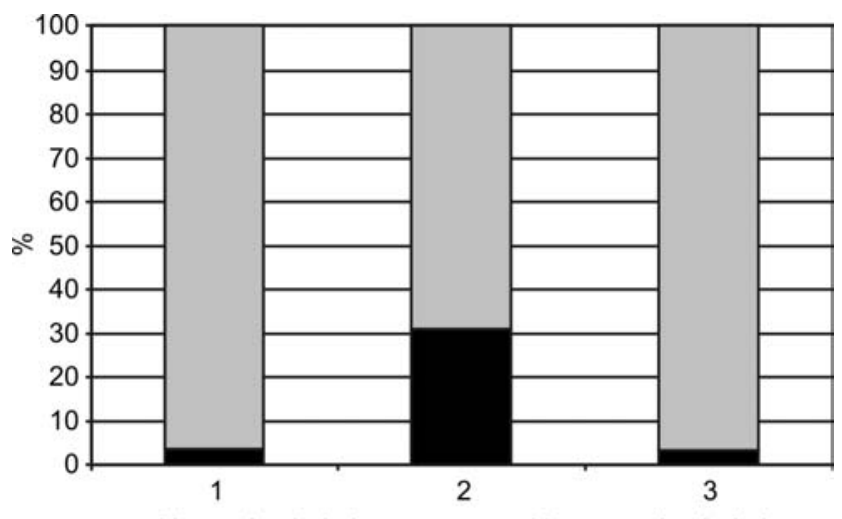

Fig. 5. Participation of the floristic recordings with purple chokeberry in the general number of recordings conducted in the areas with different human influence.

Abbreviations: 1 - extent of the peat excavation area in the 19th century; 2 - extent of the peat excavation area in the 20th century; 3 - the area of a fresh pine forest in which peat has not been excavated. it reaches $2 \mathrm{~m}$ in height; bushes are narrow, weakly branched and their fructification is poorer.

In the Chlebowo complex, purple chokeberry propagates vegetatively with the use of rhizomes, particularly in the places where the vegetation was destroyed by peat exploitation. One may assume that the majority of stands at roadsides and forest fringes were created as a result of vegetative propagation. This process is particularly easy to observe in the places where peat is currently excavated. The excavation process is preceded by the removal of the upper layer of peat with vegetation. In such places, with no competition from other species and with very good light and moist conditions, purple chokeberry propagates quickly due to its rhizomes. Specimens which come from generative reproduction have also been observed in the Chlebowo complex. This takes place on some unused roads and on quaking bogs.

Relevé 1. Birch forest (Z. C., P. Sz. 24 September 2004). Density of layer $a-80 \%$, layer $b-90 \%$, coverge of layer $\mathrm{c}<5 \%$, coverge of layer $\mathrm{d}<1 \%$; the relevé area $-100 \mathrm{~m}^{2}$; number of species - 10. Betula pendulalpubescens a 5.5, Pinus sylvestris a +; Aronia $\times$ prunifolia b 5.5, Sorbus aucuparia $\mathrm{b}+$, Frangula alnus $\mathrm{b}+.2$, Ledum palustre $\mathrm{b}+$; Vaccinium myrtillus c + , Vaccinium vitis-idaea c + , Dryopteris carthusiana $\mathrm{c}+;$ Musci $\mathrm{d}<1 \%$.

Relevé 2. Roadside (Z. C., P. Sz. 19 Oktober 2004). Density of layer $\mathrm{b}-30 \%$, coverge of layer $\mathrm{c}-10 \%$, coverge of layer $\mathrm{d}<1 \%$; the relevé area $-10 \mathrm{~m}^{2}$; number of species 16. Aronia $\times$ prunifolia b 2.2, Betula pendula b 1.1, Rubus gracilis b 1.1, Populus tremula b +; Holcus lanatus c 1.1,

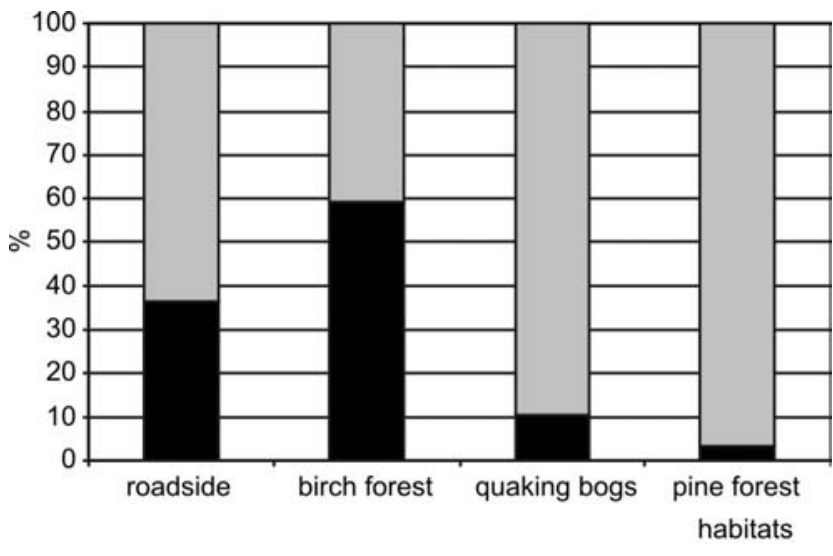

with purple chokeberry

without purple chokeberry

Fig. 6. Participation of the floristic recordings with purple chokeberry in the general number of recordings conducted in the presented habitats. 
Hypericum perforatum c 1.1, Molinia caerulea c 1.1, Artemisia vulgaris $\mathrm{c}+$, Cirsium arvense $\mathrm{c}+$, Galium mollugo $\mathrm{c}+$, Urtica dioica $\mathrm{c}+$, Vicia cracca $\mathrm{c}+$, Medicago falcata c r, Plantago lanceolata c r, Taraxacum officinale c r; Musci $\mathrm{d}<1 \%$.

Relevé 3. Quaking bog (Z. C., P. Sz. 24 September 2004). Density of layer $b-5 \%$, coverge of layer $c-60 \%$, coverge of layer $\mathrm{d}-100 \%$; the relevé area $-50 \mathrm{~m}^{2}$; number of species - 13. Pinus sylvestris b 1.1, Aronia $\times$ prunifolia $\mathrm{b}+$, Betula pubescens b +; Oxycoccus palustris c 3.4, Eriophorum vaginatum c 2.2, Typha latifolia c 1.2, Eriophorum angustifolium c 1.1, Drosera rotundifolia c + , Peucedanum palustre c + , Carex rostrata $\mathrm{c} \mathrm{r}$, Epilobium palustre c r, Lysimachia thyrsiflora c r; Musci d 5.5.

Relevé 4. Fresh pine forest (Z. C., P. Sz. 19 Oktober 2004). Density of layer $\mathrm{a}-90 \%$, layer $\mathrm{b}-15 \%$, coverge of layer $\mathrm{c}-60 \%$, coverge of layer $\mathrm{d}-70 \%$; the relevé area -50 $\mathrm{m}^{2}$; number of species - 13. Pinus sylvestris a 5.5; Aronia $\times$ prunifolia $\mathrm{b}+$, Juniperus communis b 1.1, Picea excelsa b 1.1, Rubus gracilis b 1.1, Padus serotina b + , Populus tremula b r; Vaccinium myrtillus c 4.4, Molinia caerulea c 1.1, Deschampsia flexuosa c +, Quercus robur c r, Vaccinium vitis-idaea c r; Musci d 4.4.

\section{DISCUSSION AND CONCLUSIONS}

The first observations of purple chokeberry in Poland come from the Chlebowo complex and were made in the beginning of the 1990s. In the Hereźniak's study (1992), it was erroneously recorded in that area as Aronia melanocarpa. The plant was undergoing - as it was emphasised - the whole developmental cycle in the thickets of peat vegetation complex. The number of this species was then estimated at several specimens (Hereźniak 1992).

Aronia $\times$ prunifolia has not been registered on the list of ephemerophytes of Poland (Rostański and Sowa 19861987) nor on the list of kenophytes of Poland (Zając et al. 1998). In 2004, it was only placed, together with Aronia melanocarpa, on the Internet list of alien species observed in Poland of the Institute of Nature Conservation of the Polish Academy of Sciences in Krakow (http://www.iop.krakow.pl/ias), and on the latest list of kenophytes of Poland, as a species regionally naturalised (Tokarska-Guzik 2005).

Aronia $\times$ prunifolia is cultivated in many parts of Europe and Asia (among others Popova and Gramatikov 1992; Stace 1997; Hanelt 2001; Tzvelev 2001; Kubát 2002; Rothmaler et al. 2002), and in some regions it is running wild or naturalised (e.g. Lohmeyer and Sukopp 1992; Rothmaler et al. 2002). As a permanently established anthropophyte it is recorded on bogs of the Lower Saxony (among others, Dierssen and Hülbusch 1973; Haeupler and Muer 2000), western Holland (e.g. Beek et al. 1971; Wiegers 1983, Mennema et al. 1985) and Estonia (Koltzenburg 2001). Aronia xprunifolia is an alien species for the "Bagna" bog near Chlebowo and its appearance is related to the peat excavation. Similarly to the other regions of Europe, purple chokeberry was observed in the area under study at roadsides, in forests and on quaking bogs (Figs 3 and 4). In Holland it is a well established species, forming its own communities (compare: Wiegers 1983, 1984). In Germany it enters oligotrophic bogs (Dierssen and Hülbusch 1973; Kowarik 2003). In Poland it only starts to enter the systems which, so far, have been unchanged and devoid of alien elements, like, e.g., the communities of the class Oxycocco-Sphagnetea. The area of the bog complex has been under the impact from human activity for more than 100 years. Thus, in Europe, purple chokeberry occupies the similar habitats which it prefers in its native area (North America) (Fernald 1950; Gleason 1963). In the published materials concerning this area (among others Oźminówna 1933; Czubiński and Świtalska 1937; Wodziczko et al. 1938; Ilnicki 1996) no information on the presence of the species was found. Therefore, at this stage, questions about the origin and time of appearance of purple chokeberry remain unanswered.

Purple chokeberry demands a huge amount of light. In favourable conditions it reaches 1.0-1.2 metres in height and bears a large number of fruits (even $20 \mathrm{~cm}$ long perennial shoots produce fruits). In shadowed areas it reaches over $3 \mathrm{~m}$ in height but its fructification is poorer. On the other hand, purple chokeberry requires little in terms of soil conditions. Due to its shallow root system it prefers higher levels of groundwater. It is quite tolerant to soil reaction and grows best on slightly acid soil with $\mathrm{pH}$ from 5.5 to 6.5 (Chlebowska 1999). Similar soil pH values were noted in the "Bagna" complex. Lowering of water level in post-peat excavation ponds enabled purple chokeberry to enter quaking bogs undergoing natural succession. Specimens observed on quaking bogs are low but produce an abundance of fruits. It was stated that they are separate individuals, undoubtedly, of generative origin. Diaspores may be dispersed by animals.

Aronia $\times$ prunifolia is thought to be an agriophyte in the flora of Central Europe (Lohmeyer and Sukopp 1992). In the area under study it has already reached the stage of euneophyte and its further expansion into the quaking bog vegetation, which regenerates in post-peat excavation ponds, may result in reaching the stage of a postneophyte (compare Faliński 1969). Human activity, involving the extraction of peat with the use of an open cast method, paving of roads (indispensable for the peat removal), permanent use of the roads by local inhabitants as well as the deterioration of water conditions in the constantly drained complex and droughts occurring every several years, positively influence purple chokeberry population.

\section{ACKNOWLEDGMENTS}

The authors would like to thank Prof. Jerzy Zieliński for revising the herbarium material. The scientific study was financed from the resources for science in 2004-2006 as the research project no. 3 P04G 07925.

\section{LITERATURE CITED}

BEEK A.V.D., JANSEN M.T., DE KLEUVER J.A.E., LONDO G., LEYS H.N., MARQUART J.R., MULLER F.M., VINK W. 1971. Neofieten van Midden-Nederland. Gorteria 5: 136146. (in Dutch with English summary)

CHLEBOWSKA D. 1999. Uprawa aronii. Instytut Sadownictwa i Kwiaciarstwa, Skierniewice. (in Polish) 
CZUBIŃSKI Z., ŚWITALSKA H. 1937. Torfowiska mszarne Wielkopolski i ich ochrona. Wyd. Okr. Kom. Ochr. Przyr. na Wielkopolskę i Pomorze 7: 38-57. (in Polish)

DIERSSEN K., HÜLBUSCH H. 1973. Florenliste Huvenhoopssee und Huvenhoopsmoor. Niedersächsisches Landesamt Naturschutz, Landschaftspflege, Vogelschutz. Hannover, p. 3.

DOLATOWSKI J. 1996. Drzewa i krzewy dla zieleni miejskiej i autostrad - nowości taksonomiczne. In: Chmielowski W., Dmuchowski W., Niekrasz K. (eds), Zieleń Warszawy. Problemy i nadzieje. Konferencja Naukowo-Techniczna, Warszawa-Powsin, 6 września 1996 roku, pp. 87-92. (in Polish)

FALIŃSKI J.B. 1969. Neofity i neofityzm. Ekologia polska, seria B, 15(4): 337-355. (in Polish with French summary)

FERNALD M.L. 1950. Gray's manual of botany. 8th ed. New York: American Book Co. pp. 1632.

GILL J.D., POGGE F.L. 1974. Aronia Medik, chokeberry. In: Schopmeyer C.S. (ed.). Seeds of woody plants in the United States. Agric. Handbk. 450.

GLEASON H.A. 1963. The new Britton and Brown illustrated flora of the Northeastern United States and adjacent Canada. 3 vol. New York: Hafner Publishing.

GROCHOWSKI W. 1988. Jadalne owoce leśne. Ed. V. PWRiL, Warszawa, pp. 244 (in Polish)

HANELT P. (ed.). 2001. Mansfeld's Encyclopedia of Agricultural and Horticultural Crops. 1-6, 3716 pp. Springer, Berlin.

HAEUPLER H., MUER T. 2000. Bildatlas der Farn- und Blütenpflanzen Deutschlands. Verlag Eugen Ulmer Stuttgart, pp. 759.

HEREŹNIAK J. 1992. Amerykańskie drzewa i krzewy na ziemiach polskich. In: Ławrynowicz M., Warcholińska A.U. (eds), Rośliny pochodzenia amerykańskiego zadomowione w Polsce. Łódzkie Towarzystwo Naukowe, Szlakami Nauki 19: 97-150. (in Polish with English summary)

http://www.iop.krakow.pl/ias. Allien species in Poland. Polish Academy of Science. Institute of Nature Conservation, Kraków.

ILNICKI P. 1996. Spontaniczna renaturalizacja wyeksploatowanych torfowisk wysokich. Przegląd Przyrodniczy 7(3-4): 113127. (in Polish with English summary)

KALKMAN C. 2004. Rosaceae. In: Kubitzki K. (ed.), The Families and Genera of Vascular Plants, Vol. VI, pp. 343-386. Springer-Verlag, Berlin, Heidelberg, New York.

KOLTZENBURG M. 2001. Gefäßpflanzen Estlands. http:// www.zbi.ee/ tomkukk/nimestik.

KOWARIK I. 2003. Biologische Invasionen - Neophyten und Nezozoen in Mitteleuropa. Verlag Eugen Ulmer GmbH \& Co. Stuttgart, pp. 380.

KRESS H. 2001. Plant Name Database (Version 05 April 2001). http://www.ibiblio.org/herbmed/database.html.
KUBÁT K. 2002. Klíč ke květeně České republiky. Academia, Praha, pp. 928. (in Czech)

LOHMEYER W., SUKOPP H. 1992. Agriophyten in der Vegetation Mitteleuropas. Schriftenreihe für Vegetationskunde 25: 1-185.

MABBERLEY D.J. 1997. The Plant-Book. Cambridge University Press, pp. 858.

MENNEMA J., QUENÉ-BOTERENBROOD A.J., PLATE C.L. 1985. Atlas van de Nederlandse flora 2. Zeldzame en vrij zeldzame planten. Utrecht, p. 349. (in Dutch)

MIREK Z., PIĘKOŚ-MIRKOWA H., ZAJĄC A., ZAJĄC M. 2002. Flowering plants and pteridophytes of Poland. A checklist. In: Z. Mirek (ed.), Biodiversity of Poland 1, 442 pp. W. Szafer Institute of Botany, Polish Academy of Sciences, Kraków.

OŹMINÓWNA W. 1933. Przyczynek do znajomości flory powiatu obornickiego. Wyd. Okr. Kom. Ochr. Przyr. na Wielkopolskę i Pomorze 4: 68-74. (in Polish)

POPOVA M., GRAMATIKOV D. 1992. Rosaceae. In: Delipavlov D.D., Popova M., Kovachev D.P., Tepziiski D., Cheshmdzhiev I.V., Gramatikov D. (eds), Opredelitea na rasteniyata w Bulgariya, p. 181. Zemizdat, Sofiya. (in Bulgarian)

ROSTAŃSKI K., SOWA R. 1986-1987. Alfabetyczny wykaz efemerofitów Polski. Fragm. Flor. Geobot. 31-32 (1-2): 151205. (in Polish with English summary)

ROTHMALER W., JÄGER E.J., WERNER K. 2002. Exkursionsflora von Deutschland. Band 4. Gefäßpflanzen: Kritischer Band. Spektrum Akademischer Verlag Heidelberg-Berlin, pp. 948. (in German)

SCHULZ C. 1916. Moorkultur und Naturdenkmalpflege. Zeitschrift der Natruwissenschaftlichen Abteilung des natruwissenschaftlichen Vereins 23(1): 3-8.

SENETA W., DOLATOWSKI J. 2008. Dendrologia. Wyd. Naukowe PWN, Warszawa, 544 pp. (in Polish)

STACE C. 1997. New flora of the British Isles. Cambridge University Press, Cambridge, pp. 1130.

TOKARSKA-GUZIK B. 2005. The Establishment and Spread of Alien Plant Species (Kenophytes) in the Flora of Poland. Prace Naukowe Uniw. Śląskiego w Katowicach 2372: 1-192.

TZVELEV N.N. 2001. Aronia. In: Tzvelev N.N. (ed.), Flora Europae Orientalis, 10: 555-556. Petropoli, Mir i Semia.

WIEGERS J. 1983. Aronia Medik. in the Netherlands. I. Distribution and taxonomy. Acta Bot. Neerl. 32 (5/6): 481-488.

WIEGERS J. 1984. Aronia Medik. in the Netherlands. II. Ecology of A. xprunifolia (Marsh) Rehd. in the Dutch Haf District. Acta Bot Neerl. 33(3): 307-322.

WODZICZKO A., KRAWIEC F., URBAŃSKI J. 1938. Pomniki i zabytki przyrody Wielkopolski. Wyd. Okr. Kom. Ochr. Przyr. na Wielkopolskę i Pomorze 8: 1-472. (in Polish)

ZAJĄC A., ZAJĄC M., TOKARSKA-GUZIK B. 1998. Kenophytes in the flora of Poland: list, status and origin. Phytocoenosis, Vol. 10 (N.S.) Suppl. Cartogr. Geobot. 9: 107-116. 